\title{
Case Comment: The Highway Liquor Ban Case: State of Tamil Nadu v. K. Balu \& Others
}

Satyam Tandon*

\section{Background}

The issue in this case ${ }^{1}$ was the presence of liquor vends on National and State Highways across the country which provided easily accessible liquor to the users of the highways, which led to an alarming number of road fatalities. The judgment aimed to ensure that any existing or fresh issuances of liquor licenses to liquor vends on highways was prohibited, so that road accidents could be reduced and safety of the users of the highways could be ensured. The Supreme Court observed that we should not make a nation the accident capital of the world, in the pretext of economic development. They considered the statistical data of all road accidents and concluded that an accident occurred every four minutes in India. Thereafter, the cause was identified as drunkdriving, which alone had resulted in 27,152 road accidents ${ }^{2}$. Thus, the need of the hour to curb drunk-driving on highways, was deemed worthy of immediate attention.

* OP Jindal Global University, Haryana, India; 14jgls-standon@jgu.edu.in

${ }^{1}$ State of Tamil Nadu v. K. Balu and Anr., (2017) 2 SCC 281.

2 Sanjay Mitra, Road Accidents in 2015, MINISTRY OF ROAD TRANSPORT AND HIGHWAYS, (Jul.19, 2017, 9:00 AM), http:// morth.nic.in/ showfile. asp?lid=2143. 


\section{Analysis}

The Court began its judgment by establishing that there was an urgent need to tackle the problem of easily available liquor on national and state highways, by showing the general trend of road accidents and fatalities in the past few years and how despite the various advisory circulars that were passed by the Ministry of Road Transport and Highways (MoRTH) all the States had been ignoring the same. After spelling out the problem, the Court gave the following reasons for establishing the need to solve it:

Firstly, because it had to accept the view of an expert body like the National Road Safety Council (NRSC) and MoRTH; secondly, the alarming number of road accidents caused due to drunk driving in the statistics provided; thirdly, the existence of liquor vends on highways that make procurement of alcohol on highways easy; fourthly, enforcement of the Right to Life under Article 21 and fifthly, because of the Directive Principles of State Policy laid down under Article 47 of the Constitution which state that it is the State's duty to bring about prohibition of intoxicating drinks that are injurious to health.

Further data showed that in a stretch of 291 kilometers on the Panipat-Jalandhar section of National Highway-1, there were 185 liquor shops established. Also, many liquor shops had encroached on national highway land and concrete action was yet to be taken against them, because these shops were owned by influential people and required the support of the district administration.

Thereafter, the Court considered the report filed by the OSD(Officer on Special Duty) Vigilance, before the High Court. In this report, a survey had been conducted on how the prohibition of liquor vends was likely to be tackled by the vendors. The Survey found that liquor vends were to be set up in close proximity of highways, but the entry to the shop was to be camouflaged or placed at the rear end of the vend, to evade judicial direction. The Court understood that the policy that was required had to be strict and needed absolute compliance, in order to solve this problem. The Court directed the MoRTH to revisit the policy but, they refused to do so since it was outside their purview. Thus, the Court took it upon itself and stipulated that necessary safeguards were to 
be introduced to ensure that liquor vends would not be visible or directly accessible from the highway within a stipulated distance of 500 meters from the outer edge or a service lane along the highway. But, owing to practical difficulties expressed by license holders, the current licenses were set to expire on 1st April 2017.

This judgment, however, failed to realize the importance of laying down a law that could be applicable in every circumstance and a law that was based on some sort of a test so that it can be used as a guideline for the future as well. In the present case, no such metric or test was set forth which meant that the same issue could crop up again in the future. The case should have established whether there was some sort of provocation that drove the Court to wake up and take such a decision, or was it just based on the whims and fancies of the prevalent government? It is true that the statistics demanded a change but this change, seemed draconian rather than mitigating.

On the face of it, the Court had a rational intention, but to impose a restriction of 500 meters created more problems, than it solved. And, the Order that followed immediately was a blanket ban on all liquor outlets operating within 500 meters of the highways which was a radical measure and was similar to throwing out the baby with the bath water! ${ }^{3}$ The biggest problem that this gave rise to, was the banning of liquor in areas where organized drinking took place within 500 meters of a highway. Two examples are listed below:

a. Sector 7, 26, 35 and 43 in Chandigarh": Here, the roads that run throughout the city are categorized as State and National highways because they connect the city to the highways. In fact, Harman Singh Sidhu, the man behind this Public Interest Litigation was quoted saying that

3 Costly verdict: Supreme Court's Highway Liquor Ban is Proving Counterproductive, TIMES OF INDIA,(Jul. 20, 2017, 9:08 AM), http://blogs.timesofindia.indiatimes.com/toi-editorials/costly-verdictsupreme-courts-highway-liquor-ban-is-proving-counterproductive/.

${ }^{4}$ Arvind Chhabra, Large number of bars, pubs in Chandigarh to close down as SC refuses to relax highway ban, HINDUSTAN TIMES, (Jul. 17, 2017, 11:02 AM),http://www.hindustantimes.com/punjab/most-prominent-barspubs-in-chandigarh-go-dry-as-sc-refuses-to-relax-highway-ruling-taj-jwmarriot-also-covered/story-WzpRI2ZeCltJuVjCRh62xI.html. 
highways were supposed to be outside cities and to be used only for long drives, but due to the Chandigarh authorities' mismanagement, there are many highways within the city itself as the Municipal Corporation did not have the resources to maintain them. Thus all bars, pubs, taverns and local clubs that are within 500 meters of these local roads (yet highways) would bear the brunt of cancelled liquor licenses, in spite of large investments in their businesses. To put matters into perspective, 84 out of 99 vends' licenses would be cancelled, for which the total revenue loss would amount to Rs 202.55 Crore. ${ }^{5}$

b. Cyber Hub in Gurgaon6: Another example is of the Cyber Hub in Gurgaon, which is 500 meters away from the DelhiGurgaon highway, a place that fosters 34 pubs and bars. The concern raised by the public was that unorganized drinking would be even more detrimental than making places like Cyber Hub liquor free because, people would now start drinking in their vehicles and eventually drink and drive again.

The ban was surely problematic as it should have focused on unorganized drinking, but what got impacted in the due process was organized drinking, which has its own benefits as people can avail a taxi, service that has been provided by many hotels. People are safer in such an environment rather than at a vend. Checks can be put in place to ensure that the person who is drunk is not the one who drives. Such a policy cannot practically be implemented at a vend, but can easily be done at a Bar or a Club.

To some extent the Court did carve out some exceptions in the interlocutory applications filed against the initial case. In fact, Justice Khehar stated that "they were giving themselves time to

${ }^{5}$ Road rename move in public interest,TIMES OF CHANDIGARH,(Jul. 18, 2017, 10:11 AM), http:/ / timesofindia.indiatimes.com/ city/chandigarh/ road-rename-move-in-public-interest ut/articleshow/57760917.cms.

${ }^{6}$ Leena Dhankar, Highway liquor ban: Gurgaon's cyber hub revellers left high, dry, without cheer, HINDUSTAN TIMES, (Jul. 19, 2017 11:12 AM),http://www.hindustantimes.com/gurgaon/sc-s-highway-liquorban-gurgaon-s-cyber-hub-revellers-left-high-dry-and-without-cheer/ story-tO9QJVLh7xdPzGlE19TiOK.html. 
take a conscious decision by pondering on how they need to proceed with the issue". ${ }^{7}$ The Court understood the practical difficulties of its Order and the same as listed below were taken into consideration in the subsequent Order:

a. The Court took into consideration the fact that a 500 meter limit from a highway could mean an entire town for some States and therefore decreased the limit prescribed from 500 meters to 220 meters for areas with a population of less than 20,000 people.

b. The Court had ordered all existing licenses to expire on $1^{\text {st }}$ April 2017, assuming that the financial year ended on March 31st, but stated that for some States the financial year ended on different dates, so the date was extended to $30^{\text {th }}$ September 2017 for those specific states.

c. The Court exempted Meghalaya and Sikkim from the 500 meter distance requirement since $82 \%$ of the area was forested and $92 \%$ of the trade was on the verge of collapsing if the Court's Order was complied with. ${ }^{8}$

As the unwelcome decision was passed, the Governments feared that the enforcement of this decision would cripple the tourism industry, give rise to illegal smuggling of liquor, force liquor businesses to shut down, (both organized and unorganized ones) and lead to huge losses in revenue.

Moreover, to counter this, the Chandigarh administration issued a notification to rename the state highways into major town roads 9 by reasoning that, since Chandigarh was a Union Territory it could not have any state highways. On the other hand, many places in and around Cyber Hub considered changing the entrances to their

${ }^{7}$ Liquor shops on highways: SC says need to balance road safety and vendors rights, LIVE LAW, (Jul. 20, 2017, 11:30 AM), http:// www.livelaw.in/ liqour-shops-on-highways-sc-says-need-to-balance-road-safety-andvendors-rights/.

8 State of Tamil Nadu v. K. Balu, (2017) 6 SCC 715.

${ }^{9}$ Aniruddha Ghosal, To skirt Supreme Court's liquor ban, some state highways give way, INDIAN EXPRESS,(Jul. 18, 2017, 10:53 AM), http:// indianexpress.com/article/india/to-skirt-supreme-courts-liquor-bansome-state-highways-give-way-4599832/. 
pubs, so that the drivable distance from the highway to Cyber Hub would be more than 500 meters. ${ }^{10}$ Another alternative that was brought about was the start-up in Bangalore called HipBar. This Mobile Application let customers pay for their favorite liquor brands, which stored bottles on the internet and thereafter, redeem it at any local retail store, restaurant or bar which were a part of the platform. The application witnesses bookings worth Rs1.5-2 lakh on a daily basis. ${ }^{11}$

The petitioner in this case, at the Punjab and Haryana High Court, sought the aid of the Supreme Court for an urgent hearing on the matter. ${ }^{12}$ Hence, the Court finally amended its Order and stated that denotification of highways that ran through the cities and States was allowed. Their intention was to curb drinking and driving on highways and since certain roads ceased to be highways, the ban would not apply to these roads. ${ }^{13}$

After this judgment by the Supreme Court, many other States like Karnataka followed the Chandigarh administration and moved to denotify State highways that ran inside cities into major town roads or city roads, as a way to skirt the ban. To put some numbers on the

${ }^{10}$ Abhishek Behl, Gurgaon: Cyber Hub, Ambience Mall change entrance to beat 500-metre SC liquor ban, HINDUSTAN TIMES, (Jul. 19, 2017, 10: 22 AM),http:/ / www.hindustantimes.com/gurgaon/gurgaoncyberhubambience-mall-change-entrances-to-beat-500-metre-sc-liquor-ban/storyYwWUzGQ5EavsZb2DxDc3oM.html.

11 FP Staff, Get over the liquor ban, startup HipBar app could be the answer to your drinking woes, FIRSTPOST, (Jul. 10, 2017, 9:44 AM),http:/ / www.firstpost.com/business/get-over-the-liquor-banstartup-hipbar-app-could-be-the-answer-to-your-drinking-woes3394462.html.

12Raghav Ohri, Petitioner in highway liquor ban case seeks urgent hearing on redesignating roads, ECONOMIC TIMES, (Jul. 17, 2017, 11: 33 AM),http:/ / economictimes.indiatimes.com/news/politics-andnation/petitioner-in-highway-liquor-ban-case-seeks-urgent-hearing-onredesignating-roads/articleshow/58055833.cms.

${ }^{13}$ Krishnadas Rajagopal, Liquor sale on highways: SC says it is clear on order but keeps option of changes in notification open, THE HINDU, (Jul. 20, 2017, 9:47 AM),http://www.thehindu.com/news/national/liquor-sale-onhighways-sc-sticks-to-judgment-but-keeps-option-of-denotificationopen/article19257695.ece. 
table, denotification of $700 \mathrm{kms}$ of national highways and $1746 \mathrm{kms}$ of State highways was requested by the Karnataka Government. ${ }^{14}$ Also, States like Maharashtra, Himachal Pradesh, Uttarakhand, Rajasthan and others have now denotified hundreds of kilometers of national and state highways as local, municipal or district roads. The West Bengal Government declared around $275 \mathrm{kms}$ of State Highways passing through various municipalities as arterial roads. 15

While the Maharashtra Transport Minister raised issues stating that such denotification of highways by the State Governments is equivalent to contempt of Court ${ }^{16}$, and some refusing to allow the denotification ${ }^{17}$; the Supreme Court clarified its position by saying that the purpose of the ban was to ensure that high speeding vehicles ${ }^{18}$ on highways are not driven by intoxicated drivers and nonetheless, such issues are not faced within cities. ${ }^{19}$

${ }^{14}$ Vicky Nanjappa, SC order on highway denotification to permit liquor outlets applicable throughout India, ONEINDIA, (Jul. 20, 2017, 9: 33 AM),http://www.oneindia.com/india/sc-order-on-highwaydenotification-to-permit-liquor-outlets-applicable-through-out-india2492944.html.

15 Liquor ban: State denotify highways across country after $S C^{\prime}$ 's verdict, BUSINESS STANDARD,(Jul. 9, 2017, 11: 09 AM), http://www.businessstandard.com/article/economy-policy/liquor-ban-states-denotifyhighways-across-country-after-sc-s-verdict-117040900610_1.html.

16 Denotification of highways to skirt liquor ban: Maharashtra Transport Minister voices dissent,THE INDIAN EXPRESS, (Jul. 10, 2017, 11:55 AM), http:/ /indianexpress.com/article/india/denotification-of-highways-toskirt-liquor-ban-maharashtra-transport-minister-voices-dissent4617258/.

17 Anusha Ravi, Drive safe: Madras HC stops denotification of highways to avoid booze ban, ONEINDIA, (Jul. 20, 2017, 11:22 AM), http://www.oneindia.com/india/drive-safe-madras-hc-stopsdenotification-of-highways-to-avoid-booze-ban-2416032.html.

${ }^{18}$ Liquor ban: nothing wrong with denotifying highways inside cities, says SC,DECCAN CHRONICLE,(Jul. 20, 2017, 11: 44 AM), http:// www.deccanchronicle.com/nation/current-affairs/ 040717/ liquor-bannothing-wrong-with-denotifying-highways-inside-cities-says-sc.html.

${ }_{19}$ Prabhati Mishra, Highway Liquor ban: SC refuses to stay denotification of highways in Punjab, LIVE LAW, (Jul. 10, 2017, 9:45 AM), 
This was done because most of the roads denotified by all States had their liquor pubs in and around those roads that ran within the State and they had been improperly categorized as a State highway due to lack of funding. This exception or relaxation or ignorance by the Supreme Court gives way to two further problems. The first being that this places a huge burden on the already indigent local bodies for the maintenance of the denotified highways ${ }^{20}$ and the second being that this judgment once again failed to give out a test.

The economic problem aside, the problem of withholding a test in the Order goes back to the problem raised in the judgment. Justice Khehar opined that the Court could have appreciated the fact that, if the denotified road was of the nature of a highway where there was fast moving traffic, then notification should have been mandated; but where all roads notified were inside the city, where there was no fast-moving traffic, the ban should be lifted. The metric is easily identifiable here. The test should be based on the level of traffic and usage of the road. As seen above, States are denotifying a substantial number of highways and it is imperative that the same be checked because without that, the intention behind the notification and judgment will surely be lost.

Therefore, a test must be carved out that would determine whether a road would be applicable to the 500 meter limit ban imposed or not and, it should be based on the usage and amount of vehicular traffic that the road carries. If the public uses the road as a highway, to travel long distances between cities, it must be notified as a highway and hence, fall under the 500 meter limitation, so that proper checks can be imposed and no vends, pubs or clubs can be established near it. On the other hand, if it is a city road, where there is less traffic, or it is not used to commute long distances between cities, then it must be denotified, so that liquor businesses around it can continue to operate and the unnecessary extension of the ban does not become a problem. This is important because,

http:/ / www.livelaw.in/highway-liquor-ban-sc-refuses-staydenotification-highways-punjab/.

20 Shivashankari, Highway denotification likely to burden cash-strapped ULBS more, TIMES OF INDIA,(Jul. 22, 2017, 11:57 AM), http:// timesofindia .indiatimes.com/city/bengaluru/highway-denotification-likely-toburden-cash-strapped-ulbs-more/articleshow/59101987.cms. 
after allowing States to denotify roads, it is an opportunity for them to arbitrarily avoid the ban.

Another issue that arose was the failure of the judiciary to realize that people would not mind travelling further to purchase liquor or that the liquor, vends could open 501 meters away from the highway, and in the process, the objective of this judgment is completely lost. Also, if this decision is under continuous scrutiny, what is the surety that the law would not change and lead to massive unemployment and outrage amongst the owners of liquor shops? Moreover, what would be the remedy available to those aggrieved by such a law?

In all the alternatives listed above, the practicality of the Court's judgment is scrutinized and a practical solution is founded by the Supreme Court itself. Apart from this ban, one should tackle drunk-driving by better policies, sufficient resource allocation by the State Government and constant checking of drivers on the highways. The offenders should be held liable and punished, so as to have a deterrent effect on the rest of the society. ${ }^{21}$ The intention of the Supreme Court to curb accidents was admirable and although extension of the ban on highways was necessary, it is practically impossible to enforce the same. Hence, to allow some sort of relaxation for the States, the denotification of roads has been allowed, which again gave rise to further problems. But, most importantly a test should be formalized so that such a problem does not occur again and if it does, we have a guiding authority in the form of a test based on the usage and traffic of the road.

\section{Conclusion}

The intention of the Court in adopting a pro-active approach to reduce road fatalities has been commendable but without establishing a test to denotify highways, it is paving way for the arbitrary denotification of highways by State Governments in an attempt to skirt the ban. Also, the pressure has increased upon urban local bodies for maintaining these denotified highways. Hence, by establishing a test that acts as a guiding authority on

21 Supra at 3. 
such problems, ensuring swift enforcement, penalizing drivers so as to send a warning signal to others, and prohibiting sale of liquor on highways, can definitely help solve the problem permanently. 